\title{
The conceptual framework of the impact of money supply on economic growth
}

\author{
Nadezhda Palesheva ${ }^{1, *}$, Natalia Sergievskaya ${ }^{2}$, and Andrew Prorokov $^{3}$ \\ ${ }^{1}$ Vyatka State University», Moskovskaya str., 36, Kirov, 610000, Russia \\ ${ }^{2}$ Moscow State University of Civil Engineering, Yaroslavskoe shosse, 26, Moscow, 129337, Russia \\ ${ }^{3}$ Moscow regional state University, Radio str. 10, Moscow, 129125, Russia
}

\begin{abstract}
Lately, in political and economic circles, a fierce debate on the need for additional monetary emission in Russia. The debate continues to this day. A number of economists and entrepreneurs are convinced of the need for cash injection into our economy to stimulate economic growth. They claim that lack of money hinders economic growth, because the lack of financial resources is hampering investment. At the same time criticized the Central Bank for a set them high key interest rate today at $10 \%$, which hampers not only investment in the real sector of the economy, but the current actual production. After all, profitability in most sectors of the real economy below $10 \%$. Other economists, including the Government of the Russian Federation and the Central Bank of the country, hold the opposite point of view. They believe high inflation is the main constraining economic growth factor. According to them, only after a drop in inflation, the Russian economy will be able to start growth, and additional money creation will only fuel inflation. Therefore, the first step is to suppress the rising prices, lowering inflation to $4 \%$ per annum. In this direction and concentrated all the efforts of the monetary authorities, which are primarily in the key interest rate and limit the supply of money. Of course, the dispute about such issues as stimulating economic growth by an additional cash infusion, should be resolved through analysis of the theoretical foundations and the empirical data obtained in practice, as in Russia and other countries of the world.
\end{abstract}

\section{Introduction}

This paper discusses the relationship of three important macroeconomic indicators: gross domestic product (abbreviated GDP), which reflects the economic growth; the money supply in the form of M2; inflation.

There are three primary methods of calculating gross domestic product - production, usage method (or expenditure) and income method. For the purposes of comparative and structural analysis, summarizing the various characteristics of the socio-economic situation over a period of time calculated nominal gross domestic product - GDP in current prices of the period under review. For analysis of change in gross domestic product over a certain period (first - year) calculated the rate of real GDP. At this rate, real GDP relative to the

*Corresponding author: buaia_palesheva@vyatsu.ru 
previous period (year) is calculated in comparable prices of the previous period (year). The pace of real GDP growth reflects economic growth for the period. For analysis and forecasting of macroeconomic processes over an extended period in this paper we used time series of real GDP in constant prices of the base period (year).

\section{Methods}

The proposal to stimulate economic growth through cash injections not new to economic science and practice. In 1936 in his "General theory of interest, employment and money" [5-13] the famous English economist John Maynard Keynes was scientifically substantiated the need to exit from the economic crises the government should increase their spending. Ordering of economic agents, goods and services, including the construction of a costly, but essential, infrastructure, state at the same time restores jobs, provides workers with the means of existence and creates a demand for workers produced by the same products.

Naturally, in the absence of money in the economy, their only source may be the issue of money by banks who have narrowed them to the state.

Today it is believed that due to Keynesian management techniques, the United States managed to recover from the great depression of 1929 - 1933, and in 1950 - 1960 years, the Western countries to overcome the consequences of the Second World war and to provide a stable and longstanding economic growth.

The views of the supporters of the issue of money is shared by many renowned economists. For example, Nobel laureate in Economics Paul Krugman suggested the U.S. government to sharply increase public spending for the country's withdrawal from the crisis of 2007 [4,6]. According to another economist, R. Werner, - "this approach, called productive credit, was the basis of the Japanese economic miracle. The essence of the approach to the issue of funds for specific projects involving the whole process from construction companies to manufacturing not products and its implementation" [5].

In recent years, the most frequently cited proponent of the additional injection of money into the economy is the Advisor to the President of the Russian Federation academician S. Glaziev. He believes that low energy prices and foreign sanctions and a chronic lack of resources for transactions between economic agents was the main cause of the current crisis.

According to S. Glazyev, the level of monetization of the economy, which today is approximately $40 \%,[14-16]$ predelami as the ratio of money supply to gross domestic product must be twice as higher as for example, in the United States of America [6]. At the same time, the longer the monetary authorities of Russia will delay the decision about the monetization, the deeper will be the economic downturn. "According to S. Glazyev, the growth in money supply, coupled with a number of other important management decisions, will provide our country economic growth of at least $10 \%$ per year" [5].

In the United States and several European countries, the share of Central government is zero or small, on the grounds of territorial self-organization of sport management brings their model. In some European countries such as Italy, Portugal, Hungary, other countries of Central and Eastern Europe and in Russia, the share of sports funding received from Central government, close to $50 \%$ or even exceed this value.

The share of state subsidies in the budgets of the national sports federations range from 50 to $80 \%$ depending on the sport. In some countries, for example, in Italy a significant proportion of sports funding comes at the expense of incomes from lotteries and football betting, which are accumulated at the state and local levels. Lotteries are of great importance for the income of sports organizations in countries such as Austria, Greece, Denmark, Ireland, Canada, Portugal, Finland, France and others. 
The country's tax system, primarily determines how the local communities, municipalities, lands, States and other local entities local sports organizations may rely on specific sponsors sport, the largest local taxpayers. In some countries the funding of mass sports occurs when significant involvement of the Central government, which often is the initiator of the establishment of local sports organizations, which leads to a high degree of dependence of the development of sport at local level of decisions and funding on the Central government level.

These features of funding in different countries leave their mark on a number of important characteristics of sport development at the local level:

- the pace and coordination of the construction of sports facilities,

- the level and regularity conducted at the local level of sports events

- the activity of the local sports associations in their orientation towards cooperation with major local taxpayers or Central budget;

- on the possibility of scheduling sports activities at the local level.

\section{Results}

A slightly different view is held by academician A. Aganbegyan. According to him, "money in the Russian economy is not being invested because of the "forbidden", in his words, the key rate of the Central Bank. Academician even call it the critical value - not above 8\%" [11]. At the same time, a famous scientist is not offering a cash infusion because of financial means in the land of plenty - "and so on accounts in the state banks have accumulated about 78 trillion. RUB that could have been invested in our economy" [14]

"It should be noted that today in Russia money supply is at a level less than $44 \%$ of GDP. So as of 01 January 2016, the money supply in the form of M2 was 35.81 trillion. RUB, and Russia's GDP for 2015 in nominal terms amounted to 80.80 trillion. RUB Key rate since the reduction in oil prices in late 2014 was raised to $17 \%$, which is still at a high level- 10\%. It appears that the Central Bank of Russia in its actions are guided by the principles of monetarism, which are based on transaction version of the quantity theory of money. It can be expressed a simple and clear formula I. Fisher:"

$$
\mathrm{M} * \mathrm{v}=\mathrm{Q} * \mathrm{P},
$$

Where $\mathrm{M}$ - the amount of money in circulation, $\mathrm{V}$ - the turnover of the money supply, $\mathrm{Q}-$ the volume of goods and services in real terms, $\mathrm{P}$ - the prices of goods and services.

The Central Bank of Russia assumes that the new money supply will not bring anything other than rising prices (P). Therefore, the only true way to fight inflation is to limit the amount of money in economic circulation.

\section{Discussion}

"Inflation, in accordance with the Order of Rosstat of Russia from 30.12.2014 No. 734 is a socio-economic phenomenon, characterized by a General increase in the level of prices as a result of depreciation of cash and non-cash money and reduce their purchasing power" $[2,10]$. the Main indicator of inflation is the consumer price index and tariffs for goods and services purchased by the population. It measures the ratio of the value of a fixed list of goods and services in the prices of the current period to its cost in the prices of the previous (base) period.

"Gross domestic product refers to the final result of production activities of resident units producing for a certain period of time and is calculated in market prices" [3,11]. In Other words, GDP is a measure that reflects the market value of all final goods and services 
(that is intended for direct consumption) produced per year in all sectors of the economy in the state for consumption, export and accumulation.

In addition, "an international comparison using the method of calculation of GDP at purchasing power parity, taking into account a comparable level in the studied countries" $[1,9]$.

"M2 represents the money supply in the country, which includes cash in the hands of the population, the population's deposits and deposits of financial and non-financial organizations, except credit institutions." [2,7,9] Federal reserve system of the United States gives approximately the same definition in M2 [4,6,9] although many countries have their own peculiarities of this definition.

\section{Conclusions}

Some media appear to support supporters of the expansion of the money supply, and with the bringing of evidence based on statistical data. The most resonant, in our opinion, is the article by S. Blinov in the electronic version of the journal "Expert" [6,7]. In it the author cites statistics on the growth of gross domestic product, inflation and M2 money supply, putting under question the effectiveness of restrictive actions of the current economic managers in the Government and the Central Bank of Russia.

An article in the journal "Expert contains two main points: money supply growth in Russia over the period 1998 to 2015 does not provoke inflation, that is not a cause of increase in consumer prices; money supply growth leads to GDP growth. A feature of the above theses is a complete contradiction of the current from the beginning of 1990-ies in our country's monetary ideology, according to which everything is just the opposite: the growth in the money supply causes inflation and thus limits the growth of gross domestic product.

In connection with the above, the question arises about the existence of a stable relationship of money supply with economic growth. Indeed, in the case of such connection, even in a certain range, it is possible to implement monetary policy in such a way as to ensure maximum growth in gross domestic product of the country and welfare of its citizens.

\section{References}

1. R. Werner, Japan's Central Bankers and the Transformation of the Economy (New York, 2011)

2. An.B. Mottaeva, As.B. Mottaeva, International Journal of Applied Engineering Research 1, 10- 23 (2015)

3. An.B. Mottaeva, As.B. Mottaeva, International Journal of Applied Engineering Research 1, 11- 9 (2016)

4. N.G. Verstina, T.S. Meshcheryakova, Biosciences Biotechnology Research Asia, 12 2 (2015)

5. A. Mottaeva, MATEC 73, 07020 (2016)

6. A.B. Mottaeva, A. Zheltenkov, I. Stukanova, S. Ryabichenko, S. Zhuk, MATEC 73, 07026 (2016)

7. L.V. Nikolova, D.G. Rodionov, A.B. Mottaeva, International Journal of Economics and Financial Issues 6(S3), 1-7 (2016)

8. T. Miroshnikova, N. Taskaeva, MATEC 73, 123284 (2016) 
9. A. Pimenova, S. Kuzmina, N. Morozova, A. Mottaeva, MATEC 73, 07018 (2016)

10. Stein, E., Taskaeva, N. , Chibisova, E. Procedia Engineering, Volume 165, 1410$1416(2016)$

11. A.I. Shlafman, Rossijskoe predprinimatel'stvo 1, 25-29 (2009)

12. N.G. Verstina, E.M. Akimova, T.N. Kisel, N.N. Taskaeva, Asian Social Science 1, 11-14 (2015)

13. N.G. Verstina, T.S. Meshcheryakova, Biosciences Biotechnology Research Asia 1, $12-$ $2(2015)$

14. I. Polyakova, E. Vasilyeva, Procedia Engineering, 165 (2016)

15. The order of Rosstat from 30.12.2014 No.734

16. Business-gazeta.ru/article/124749 